\title{
Leadership Styles of Senior and Middle Level Managers: A Study of Selected Firms in Muscat, Sultanate of Oman
}

\author{
G. P. Mishra ${ }^{1}$, Donald Grunewald ${ }^{2} \&$ Neelufer Aslam Kulkarni ${ }^{1}$ \\ ${ }^{1}$ Department of Management, Waljat College of Applied Science, Muscat, Sultanate of Oman \\ 2 Department of Strategic Management, Iona College, New York, U.S.A \\ Correspondence: Neelufer Aslam Kulkarni, Department of Management, Waljat College of Applied Sciences, P. \\ O. Box 197, Rusayl, P.C. 124, Muscat, Sultanate of Oman. Tel: 968-9617-4054. E-mail: neelufer@waljat.net
}

Received: June 5, 2014

doi:10.5539/ijbm.v9n11p72
Accepted: September 1, 2014

Online Published: October 22, 2014

URL: http://dx.doi.org/10.5539/ijbm.v9n11p72

\begin{abstract}
The paper identifies the leadership styles with of senior and middle level managers and their relationship with the financial performance of the selected fast moving consumer goods firms in Muscat, Sultanate of Oman. A co relational descriptive research design was used. Data about leadership styles was collected from senior and middle level managers through two instruments: the Multi Factor Leadership Questionnaire 5X and the Leadership Styles Scale. Mean, t- test, Pearson correlation and ANOVA was used for data analysis. Results reveal that there is no significant difference in the leadership styles of senior and middle level managers, managers of high performing firms use transformational leadership style and there is a significant relationship between leadership style and financial performance. It is thus suggested that firms should train their managers to use transformational leadership style.
\end{abstract}

Keywords: leadership styles, senior level managers, middle level managers, FMCG firms, Muscat

\section{Introduction}

There is a great demand of Leadership in various organizations. Even today's strategic persons working in the organization like C.E.O's need to have great skills of Leadership to run the organization effectively. (Salleh \& Grunewald, 2013). The contemporary organization faces numerous challenges. External factors like the unstable world and national economy and internal conditions like human resource mismanagement and unsatisfied customers risk the overall operations of the firm. The success or failure of a firm depends largely on how the senior and middle level managers shape and execute the organization's strategies. Leadership is a catalyst, which transforms the organization into a more profitable and productive one. However, the extent of this success depends largely on the leadership style adopted by the senior and middle level managers. Every successful firm has one major characteristic that distinguishes it from average or unsuccessful ones: dynamic and effective leadership. Thus, Leadership plays an important role in any organization.

Reviews of earlier studies highlight the importance of leadership styles in increasing work group effectiveness (Dixon \& Hart, 2010), followers' collective identity and perceptions of unit performance (Singh \& Krishnan, 2008), organizational profitability and success (Valdiserri \& Wilson, 2010), goal orientation (Pastor \& Mayo, 2008), knowledge creation (Mitchell \& Boyle, 2009), collective efficacy (Walumba, Wang, \& Lawler, 2004), trust, satisfaction and organizational citizenship behavior (Podskaoff \& Mackenzie, 1990) and extra effort, satisfaction and effectiveness (Bennett, 2009).

Researchers are however of diverse opinions as to whether leadership styles can influence the firm's performance. Some researchers (Waldman, Bass, \& Yammarino, 1990) opine that leadership style, the role and responsibilities of the leaders, their adaptability to complex competitive environment affect the firm's success. They argue that as leaders direct and motivate subordinates to perform tasks efficiently, the style used in the direction and motivation is an important determinant of performance. According to Michael (2011) there is a direct relationship between leadership style and success as without good decisions organizations will be unable to perform. Other theorists (Meindl, 1990) argue firms which lack appropriate resources will be unsuccessful. Even favorable leadership style will not be able to influence performance.

The authors observe a study to identify the leadership styles of senior and middle level managers in Fast Moving 
Consumer Goods firms in Muscat has not been conducted. Further, the impact of leadership styles on the performance of FMCG firms in Muscat has not been examined. This study will provide an insight into the leadership styles of senior and middle level managers and will highlight its importance in making successful FMCG firms.

\subsection{Purpose of the Study}

The study investigates the leadership styles of senior and middle level managers in selected Fast Moving Consumer Goods Firms in Muscat, Sultanate of Oman. It further examines whether leadership styles affect the performance of the selected FMCG firms located in Muscat. The following research questions guided the study:

1) What are the leadership styles of the senior and middle level managers in selected Fast Moving Consumer Goods Firms in Muscat?

2) Are there any significant differences in the leadership styles of senior and middle level managers in the selected FMCG firms in Muscat?

3) Do the leadership styles of the senior and middle level managers have a significant relationship with organizational performance?

\subsection{Hypothesis}

The Null hypothesis for the study was formulated as follows:

$\mathrm{H}_{01}$ : Leadership styles of senior and middle level managers have no significant relationship with the organizational performance of selected firms in Muscat.

$\mathrm{H}_{02}$ : There is no significant difference in the leadership styles of senior and middle level managers of high, mediocre and low performing firms.

\subsection{Scope of the Study}

The scope of the study is limited to leadership styles of senior and middle level managers of Joint Stock Fast Moving Consumer Goods Companies located in Muscat. Specifically firms listed under the industrial sector and sub sector food in the Muscat Securities Market were selected. The leadership styles included in this study are Autocratic, Bureaucratic, Democratic, Paternalistic, Transformational, Transactional and Laissez Faire.

\section{Literature Review}

\subsection{Leadership Theories}

There are several distinct theoretical bases for leadership. One of the earliest approaches, the great man theory, implied that leaders are born and not made. This approach came to be associated with the traits approach, which was concerned with identifying the personality traits of great leaders. Several drawbacks were identified with this approach and the emphasis shifted to the followers. In the behavior approach, leadership is viewed in terms of leader behavior and how it affects and is affected by the followers. The situational approach viewed the leader as a product of the situation and time. All the established theories of leadership continue to provide understanding and foundation for the practice of leadership in today's organization.

In the recent years, a number of alternative theories have emerged to supplement and facilitate better understanding of the effective leadership processes. The most important among them are the Charismatic and Transformational Leadership Theory. Charismatic leaders get extra ordinary commitment and performance from the leaders. Transformational leaders are characterized by charisma, inspiration, and intellectual and individualized consideration. These leaders bring about a dramatic change in the organization.

\subsection{Leadership Style Theories}

Leadership style is the consistent behavior pattern that leaders use when they are working with other people as perceived by those people. Eagly and Johannesen-Schmidt (2001), defined leadership style as "relatively stable pattern of behavior exhibited by leaders". The total pattern of explicit and implicit leader's action as seen by employees is called leadership style. Leaders apply different leadership styles depending on the followers and the organizational environment. A leader may use all the styles but one style tends to dominate. Following is a brief description of the leadership styles investigated in this study.

\subsubsection{Autocratic Leadership Style}

Leaders using the autocratic leadership style take as many decisions as possible with minimum consultation with colleagues and sub ordinates. They have the utmost authority in decision-making. Autocratic leaders retain responsibility for their decisions and do not delegate their responsibilities. Autocratic leadership style is still 
practiced by many leaders across the globe as it is instinctive and comes natural to many leaders.

\subsubsection{Bureaucratic Leadership Style}

Bureaucratic leadership style ensures that employees abide by the rules and regulations of the organization. Bureaucratic leadership style is characterized by display of impersonal relationship with the organizational members. Bureaucratic leaders gain instant authority with their position, because rules demand that employees pay them certain privileges. The top management frames the rules, regulations and procedures and all the employees are expected to follow them perfectly and consistently. Bureaucratic leadership style is usually found in large and old businesses.

\subsubsection{Democratic Leadership Style}

Democratic managers promote the sharing of responsibility, the exercise of delegation and continual consultation with subordinates. The Democratic leader drafts policies after group discussions and acceptance. He/ She makes it clear that praise and blame is a matter for the group. Senior and Middle level managers using democratic leadership style welcome feedback on the results of initiatives and the work environment and encourage subordinates to become leaders and be involved in leadership development.

\subsubsection{Paternalistic Leadership Style}

Paternalistic leaders act as a father figure and take care of their subordinates as a parent would. In this leadership style, the senior and middle level manager is concerned about his/her employees. In return, the leader receives the complete trust and loyalty of the employees.

\subsubsection{Transactional Leadership Style}

Transactional leaders set the organization's goals and objective. They achieve these goals by clarifying the roles and tasks of the employees. These leaders set rules and standards and monitor for any deviations. They motivate sub ordinates towards achieving the goals by rewarding and offering promises of reward for good performance. Thus, the transactional leadership style is an exchange relationship between the leader and the followers.

\subsubsection{Transformational Leadership Style}

Transformational leaders achieve the organizations goals by painting a future vision of the organization and inspiring employees to be a part of and achieve that vision. This style of leadership creates a sense of duty within the organization, encourages new ways of handling problems and promotes learning for all organizational members. They pay attention to the concerns and development needs of the individual followers. Thus, Transformational leadership is based on leaders shifting values, beliefs and needs of the followers.

Reviews of earlier studies highlight the importance of leadership styles. Lewin, Lippit \& White (Lewin, Lippit, \& White, 1939) found that democratic leadership style increased work mindedness among the followers, Shaw (Shaw, 1995) concluded that autocratically supervised subjects required less time to solve the problems and made fewer errors. Day and Hamblin (Day \& Hamblin, 1964) claimed that subjects exposed to autocratic leaders produced less than did subjects, exposed to democratic leaders. Thus, there is no agreement among researchers about the impact of Democratic and Autocratic leadership style.

Dixon, M. L., \& Hart, L. (2010) found that there is a statistically significant relationship between Path goal leadership style and work group effectiveness where as Niti and Krishnan (2008) reported a positive relationship between transformational leadership, and followers' collective identity and perceptions of unit performance. Valdiserri \& Wilson (2010) established a positive relationship between leadership style and organizational profitability and success. Transformational leadership style is shown to have a positive association with goal orientation (Pastor \& Mayo, 2008), knowledge creation (Mitchell \& Boyle, 2009), collective efficacy (Walumba, Wang, \& Lawler, 2004), trust, satisfaction and organizational citizenship behavior (Podskaoff \& Mackenzie, 1990) and extra effort, satisfaction and effectiveness (Bennett, 2009). A study examining the full range leadership model in the Sultanate of Oman is conspicuous by its absence. This study aims to fulfill this void by identifying leadership styles put forth by the behavioral theory (Autocratic, Bureaucratic, Democratic and Paternalistic) and the modern full range leadership theory (Transformational, Transactional and Laissez Faire) in the context of FMCG firms in Oman.

\subsection{Leadership Styles and Firm Performance}

The role of leadership and leadership styles in improving organizational performance has long been debated. (Fiedler, 1996) in a treatise on the importance of leadership states that it is the main determinant of the success or failure of the firm. Some researchers (Avolio, 1999; Rowe, 2001) argue that leadership is a source of sustained competitive advantage and responsible for improvement in firm performance. Mehra et al conclude that some 
firms perform better than other because of better and effective leadership style. Yukl (2002) in his book 'leadership in Organisations' states that changes in CEO account for changes in organizational performance.

Pfeffer (1977) states that leadership has no effect on performance. He justifies his conclusions by stating that the selection and promotion of the leader is as per rules and criteria set by the organization. Secondly, leader behavior is conditioned by social norms and external forces. Lastly, he states that the environmental factors are primarily responsible for differential performance. Liberson \& O'Corner (1972) selected 167 organisations from 13 industries to study the influence of environment, corporate and leadership factors on sales, earnings and profit margins. The outcome of this longitudinal study from 1946 to 1965 was that environmental factors cause more variance in firm performance than leadership. These studies however are criticized for their methodological problems. Weiner \& Mahoney (1981) replicated Libersons study and contrarily found that leadership accounts for more variance as compared to environmental factors.

Review of literature on leadership styles and its impact, outcome and effects shows that there is no uniformity in the concept of leadership and organizational performance. Thus, it is not possible to directly compare the findings of the previous researchers. Secondly, there is no unanimous agreement as about the existence and nature of relationship between leadership styles and performance. Thirdly and most importantly, our literature search from 1936 till date reveals that there is no empirical published work on leadership styles of senior and middle level managers and their impact on the firm performance in the Sultanate of Oman. This study proposes to bridge this gap by examining leadership styles of senior and middle level managers in Fast Moving Consumer Goods Firms in Muscat, Sultanate of Oman and their impact on the performance of these firms. The leadership styles included in the study are Autocratic, Bureaucratic, Democratic, Paternalistic, Transformational, Transactional and Laissez Faire. Average Net Profits from 2008 to 2012 is used as an indicator of performance.

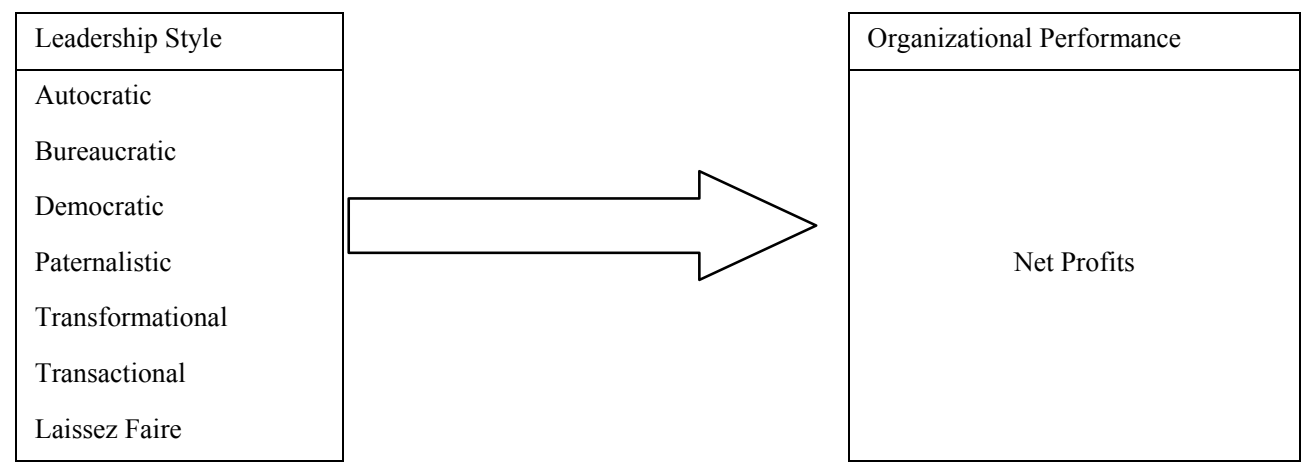

Figure 1. The relationship between leadership style and organizational performance

Source: Researchers own construct.

\section{Methodology}

\subsection{Research Design}

The study employs a quantitative and survey research method. A co relational descriptive research design was used to determine the relation between the independent variables Autocratic, Bureaucratic, Democratic, Paternalistic, Transformational, Transactional and Laissez Faire leadership styles and the dependent variable financial performance of the firm.

\subsection{Sample Design and Sampling Technique}

Firms listed in the Muscat Securities market, under the leadership of the same Chief Executive Officer from 2008 to 2013 and which had headquarters or main office in Muscat, the capital city of Sultanate of Oman were included in the study. This selection criterion resulted in 10 Fast Moving Consumer Goods firms whose primary activities were production and distribution of chips, biscuits, oil, mineral water, juices, flour and poultry products. All the Chief Executive Officers of these firms formed the senior level managers of the sample. Five middle level managers, who were in the organization since 2008, were randomly selected from each firm. Fifty respondents completed the questionnaire giving a response rate of $83.33 \%$.

\subsection{Research Instrument}

Two research instruments were used to measure leadership style: The Leadership Styles Scale (Oates, 2010) 
developed by Simon Oates and The Multifactor Leadership Questionnaire 5X Short developed by Bass and Aviolio. The leadership Styles Scale is a 24 -item instrument and has 4 subscales to measure Autocratic, Bureaucratic, Democratic and Paternalistic Leadership Style. The instrument uses a 5-point Likert rating scale (0: Strongly disagree; 1: Disagree, 2: Neutral, 3: Agree, 4: Strongly agree).The Multifactor Leadership Questionnaire is a collection of 36 items and measures Transformational, Transactional and Laissez Faire Leadership style. The respondent has to judge how frequently each statement fits him or her. The anchors used to evaluate the MLQ factors are $0=$ Not at all, $1=$ Once in a while, $2=$ Sometimes, $3=$ Fairly often, $4=$ Frequently, if not always. Internal reliability of the two instruments was determined using Cronbach's alpha. The reliability scores for each style of the Leadership Styles Scale are: Autocratic (0.83), Bureaucratic (0.72), Democratic (0.87), Paternalistic (0.71). Cronbach alpha for the dimensions measured on MLQ are Transformational leadership style (0.89), Transactional (0.70) and Laissez Faire (0.68).

The dependent variable, organizational performance was measured as the average of net profits from 2008 to 2012.

\subsection{Data Collection Procedure}

An email followed by a telephone call to explain the purpose, significance and utility of the research to the senior level managers was made. Managers of all the firms consented to be a part of the study. Appointments were fixed to personally collect data with regards to leadership style. The Human Resource Department gave the email addresses of the middle level managers who were in the organization since 2008. Questionnaires were e mailed to middle level managers. The respondent senior and middle level managers rated their leadership style.

The average of the Net Profits of the firms from 2008 to 2012 was used as a measure of the financial performance of the firms. Financial details of the firm were obtained from the MSM Companies Guide 2013.

\section{Results}

To answer the first research question: What are the leadership styles of the senior and middle level managers in selected Fast Moving Consumer Goods Firms in Muscat? An average of the responses was obtained to find the mean score for the leadership style. Table 1 shows the descriptive analysis for leadership styles of senior and middle level managers. From Table 1 it can be observed that managers of FMCG firms frequently use Transformational leadership style. Senior level managers rated themselves as more Transformational as compared to middle level managers. The other dominant styles are Democratic and Paternalistic leadership style. Senior and middle level managers had a similar average for Paternalistic leadership style. The mean score for democratic leadership style of middle level managers is higher than that of senior level managers. Both senior and middle level managers rarely use Laissez Faire leadership style.

Table 1. Summary of leadership styles of senior and middle level managers

\begin{tabular}{|c|c|c|c|c|c|c|c|}
\hline \multirow{2}{*}{ Leadership Style } & \multicolumn{2}{|c|}{ Senior Managers } & \multicolumn{2}{|c|}{ Middle Level Managers } & \multirow{2}{*}{$\mathrm{t}$-value } & \multirow{2}{*}{$\begin{array}{l}\text { Sig } \\
\text { (two-tailed) }\end{array}$} & \multirow{2}{*}{ Result } \\
\hline & Mean & Standard Deviation & Mean & Standard Deviation & & & \\
\hline Autocratic & 2.48 & 0.70 & 2.40 & 0.64 & 0.71 & 0.48 & NS \\
\hline Bureaucratic & 2.24 & 0.89 & 2.26 & 0.83 & 0.13 & 0.89 & NS \\
\hline Democratic & 2.57 & 0.76 & 2.63 & 0.64 & 0.48 & 0.64 & NS \\
\hline Paternalistic & 2.53 & 0.68 & 2.51 & 0.84 & 0.14 & 0.89 & NS \\
\hline Transformational & 2.77 & 0.81 & 2.67 & 0.77 & 0.71 & 0.48 & NS \\
\hline Transactional & 2.47 & 0.89 & 2.44 & 0.77 & 0.21 & 0.84 & NS \\
\hline Laissez Faire & 1.03 & 0.79 & 0.89 & 0.83 & 0.90 & 0.32 & NS \\
\hline
\end{tabular}

Note. NS $=$ Not Significant at $1 \%$ and $5 \%$ level of Significance.

A t-test was carried out to answer the second research question: Are there any significant differences in the leadership styles of senior and middle level managers in the selected FMCG firms in Muscat? Results of the ttest, as reported in Table 1, reveal that there is no significant difference in the leadership style of senior and middle level managers. We can thus conclude that the leadership style of both senior and middle level managers of FMCG firms in Muscat are similar. 
The FMCG firms were assigned ranks based on the average net profits. Leadership styles of senior and middle level managers in each firm were determined.

Table 2. Leadership styles and ranking of FMCG firms

\begin{tabular}{lll}
\hline $\begin{array}{l}\text { Rank of } \\
\text { FMCG Firm }\end{array}$ & $\begin{array}{l}\text { Average } \\
\text { Net Profits }\end{array}$ & $\begin{array}{l}\text { Leadership Style of the Managers } \\
\text { (Dominant Style 1,Style 2) }\end{array}$ \\
\hline 1 & 16,086 & Transformational, Democratic \\
2 & 10,490 & Transformational, Paternalistic \\
3 & 7,186 & Transformational, Paternalistic \\
4 & 6,742 & Transformational, Democratic \\
5 & 4,365 & Transactional, Transformational \\
6 & 2,619 & Transactional, Autocratic \\
7 & 1,532 & Transactional, Autocratic \\
8 & 1,454 & Transactional, Bureaucratic \\
9 & 667 & Bureaucratic, Transactional \\
10 & -26 & Autocratic, Transactional \\
\hline
\end{tabular}

The above table shows the dominant and second most frequently used style in each of the firm. Results reveal that the dominant leadership style of the senior and middle level managers in the first four firms is Transformational, followed by transactional, Bureaucratic and Autocratic. The second most frequently used style in the top ranking firms was democratic or paternalistic.

From Table 2, we can infer that the dominant leadership style in the top 4 performing Fast Moving Consumer Goods firms is Transformational leadership style. The second most frequently used style is democratic or paternalistic. The dominant leadership style of the $5^{\text {th }}, 6^{\text {th }}, 7^{\text {th }}$ and $8^{\text {th }}$ ranked firms are Transactional and the other most frequently used style is Autocratic and Bureaucratic. Dominant leadership styles of the lowest ranking firms are Bureaucratic and Autocratic.

To test the hypothesis: Leadership styles of senior and middle level managers have no significant relationship with the organizational performance of selected firms in Muscat. Pearson's Bivariate Correlation test was used. Correlation between leadership style and organizational performance, as presented in Table 3, show that there exists a significant relation between Autocratic, Bureaucratic, Democratic, Paternalistic, Transformational and Transactional leadership style and organizational performance..

Table 3. Correlation between leadership style and firm performance

\begin{tabular}{llllll}
\hline Variables & Mean & $\begin{array}{l}\text { Standard } \\
\text { Deviation }\end{array}$ & $\begin{array}{l}\text { Organizational } \\
\text { Performance }\end{array}$ & Sig(2 tailed) & Result \\
\hline Autocratic & 2.44 & 0.67 & -0.387 & 0.000 & $*$ S \\
Bureaucratic & 2.25 & 0.86 & -0.186 & 0.018 & $* \mathrm{~S}$ \\
Democratic & 2.60 & 0.70 & 0.419 & 0.015 & $* \mathrm{~S}$ \\
Paternalistic & 2.52 & 0.76 & 0.375 & 0.033 & $* \mathrm{~S}$ \\
Transformational & 2.72 & 0.79 & 0.586 & 0.000 & $* \mathrm{~S}$ \\
Transactional & 2.46 & 0.83 & 0.218 & 0.021 & $\mathrm{NS}$ \\
Laissez Faire & 0.96 & 1.82 & 0.109 & 0.980 & \\
\hline
\end{tabular}

Source: SPSS Output.

Note. $* \mathrm{~S}=$ Significant at $5 \%$ Level of Significance; $* * \mathrm{~S}=$ Significant at $1 \%$ Level of Significance; $\mathrm{NS}=$ Not Significant at $1 \%$ and $5 \%$ level of Significance.

Democratic, Paternalistic, Transformational and Transactional leadership styles have a significant and positive correlation with organizational performance whereas Autocratic and Bureaucratic leadership styles have a significant negative correlation with performance. Transformational Leadership style is strongly related to the firm performance.

To further clarify the role of leadership styles in the performance of FMCG firms; the organizations were classified as high, mediocre and low performers. The quartile values of the average net profits were used for this 
classification. The mean scores for the leadership styles were compared using ANOVA. The firm groups were used as independent variables and leadership style as dependent variables. Results are presented in the table below:

Table 4. Leadership styles and firm group

\begin{tabular}{lllllll}
\hline \multirow{2}{*}{ Firm Group } & \multicolumn{5}{c}{ Leadership Styles } \\
\cline { 2 - 6 } & Autocratic & Bureaucratic & Democratic & Paternalistic & Transactional & Transformational \\
\hline High Performer & 1.79 & 1.86 & 3.02 & 2.98 & 2.65 & 3.12 \\
Mediocre Performer & 2.54 & 2.38 & 2.43 & 2.40 & 2.89 & 2.78 \\
Low Performer & 3.12 & 2.73 & 1.57 & 1.96 & 2.03 & 1.79 \\
F & 3.27 & 5.61 & 3.48 & 4.05 & 5.85 & 2.76 \\
Sig & 0.03 & 0.002 & 0.03 & 0.02 & 0.004 & 0.05 \\
Result & $* \mathrm{~S}$ & $* * \mathrm{~S}$ & $* \mathrm{~S}$ & $* \mathrm{~S}$ & $* \mathrm{~S}$ & $* \mathrm{~S}$ \\
\hline
\end{tabular}

Source: SPSS Output;

Note. $* \mathrm{~S}=$ Significant at $5 \%$ Level of Significance; $* * \mathrm{~S}=$ Significant at $1 \%$ Level of Significance; ANOVA results show that there is a significant difference in the leadership styles of senior and middle level managers of high, mediocre and low performing firms.

\section{Discussions}

This study identified the leadership styles of senior and middle level managers of selected FMCG firms in Muscat, Sultanate of Oman. From the results of the study, it can be concluded that the managers of successful firms use transformational leadership style. Managers of Mediocre firms adopted Transactional style where as low performers had bureaucratic and autocratic leaders. Results of t-test proved that there is no significant difference in the leadership styles of senior and middle level managers. Results also prove that leadership style has a significant correlation with firm performance. Transformational leadership style is positively co related to performance where as autocratic style is negatively co related. By changing the values, beliefs and needs of the followers, transformational leaders can achieve performance beyond expectations.

\section{Conclusion and Recommendation}

Based on the findings, the authors conclude that leadership styles have a positive and negative relationship with firm performance. As transformational, paternalistic and democratic leadership style are strongly positively correlated to firm performance, managers of low performing firms should be advised and trained to use these preferred styles. Usage of these leadership styles may help these firm to improve their performance and among the high performer firms groups.

The study utilizes only financial performance as a measure of organizational performance. A further study can be undertaken, which includes performance measures such as business performance, organizational effectiveness and performance intent.

\section{References}

Bass, B. (1990). Bass and Stogdill's handbook of leadership. New York: Free Press.

Bennett, T. M. (2009). A Study Of The Management Leadership Style Preferred By It Subordinates. Journal of Organizational Culture, Communications and Conflict, 13(2), 1-26.

Day, R. C., \& Hamblin, R. L. (1964). Some Effects of Close and Punitive Styles of Supervision. American Journal of Psychology, 61, 499-510.

Dixon, M. L., \& Hart, L. (2010). The Impact of Path-Goal Leadership Styles on Work Group Effectiveness and Turnover Intention. Journal of Managerial Issues, 22(1), 56-69.

Dixon, S. E., \& Day, M. (2008). Leadership, administrative heritage and absorptive capacity. Leadership \& Organization Development Journal, 727-748.

Fiedler, F. E. (1996). Research on Leadership Selection And Training: One View of the Future. Administrative Science Quaterly, 41, 241-250. http://dx.doi.org/10.2307/2393716

Lewin, K., Lippit, R., \& White, R. (1939). Patterns of Aggressive Behavior in Socially Created Climates. Journal of Psychology, 271-299. 
Lieberson, S., \& O’Corner, J. F. (1972). Leadership \& Organizational Performance: A Study of Large Corporations. American Sociological Review, 37, 117-130. http://dx.doi.org/10.2307/2094020

Luthans, F. (2005). Organizational Behavior. Mumbai: Mc Graw Hill.

Meindl, J. R. (1990). Leadership-An Alternative to The Conventional Wisdom. Research in Organizational Behavior, 12, 159-203.

Mitchell, R. J., \& Boyle, B. (2009). A theoretical model of transformational leadership's role in diverse teams. Leadership \& Organisation Developmnent Journal, 30(5), 455-474. http://dx.doi.org/10.1108/01437730910968714

Pastor, J. C., \& Mayo, M. (2008). Transformational leadership among Spanish upper echelons. Leadership \& Organization Development Journal, 340-358. http://dx.doi.org/10.1108/01437730810876140

Pfeffer, G. (1977). The Ambiguity of Leadership. Academy of Management Review, 12(1), 205-211.

Podskaoff, P. M., \& Mackenzie, S. (1990). Transformational Leader Behaviors and their effects on Followers Trust in the Leader,Satisfaction and Organisational Citizenship Behaviors. Leadership Quaterly, 107-142. http://dx.doi.org/10.1016/1048-9843(90)90009-7

Rowe, W. G. (2001). Creating Wealth in Organisations:The Role of Strategic Leadership. Academy of Management Executives, 15(1), 81-94. http://dx.doi.org/10.5465/AME.2001.4251395

Salleh, M., \& Grunewald, D. (2013). Organizational Leadership-The Strategic Role of the Chief Exec. Journal of Leadership, Accountability, and Ethics, 10(5), 9-20.

Shaw, M. E. (1955). A Comparision Of Two Types Of Leadership In Various Communication Nets. Journal of Abnormal and Social Psychology, 127-134. http://dx.doi.org/10.1037/h0041129

Singh, N., \& Krishnan, V. R. (2008). Self-sacrifice and transformational leadership: mediating role of altruism. Leadership \& Organization Development Journal, 29(3), 261-274. http://dx.doi.org/10.1108/01437730810861317

The role of collective efficacy in the relations between transformational leadership and work outcomes. (2004). Journal of Occupational and Organizational Psychology, 77(4), 515-530.

Valdiserri, G. A., \& Wilson, J. L. (2010). The Study of Leadership in Small Business Organizations: Impact on Profitability and Organizational Success. Entrepreneurial Executive, 15.

Waldman, D. A., \& Yammarino, F. J. (1990). CEO Charismatic Leadership: Levels-of- Management and Levels-of-Analysis Effects. Academy of Management Review, 24(2), 266-285. http://dx.doi.org/10.1177/105960119001500404

Waldman, D. A., Bass, B. M., \& Yammarino, F. (1990). Adding to the contingent Reward Behavior: The Augmenting Role of Charismatic Leadership. Group \& Organization Management, 15(4), 381-394.

Weiner, N., \& Mahoney, T. A. (1981). A Model of Corporate Performance as a Function of Environmental, Organisational \& Leadership Performance. Academy of Management Journal, 24, 453-470. http://dx.doi.org/10.2307/255568

Yukl, G. (2002). Leadership in Organisations. Upper Saddle River, NJ: Prentice Hall.

\section{Copyrights}

Copyright for this article is retained by the author(s), with first publication rights granted to the journal.

This is an open-access article distributed under the terms and conditions of the Creative Commons Attribution license (http://creativecommons.org/licenses/by/3.0/). 